\title{
Comparative Study of Divergent Thinking among Participants in a German Science Competition and Pupils in a Control Group
}

\author{
Swantje Müller ${ }^{1}$, Verena Pietzner ${ }^{1 *}$ \\ 1 University of Oldenburg, GERMANY
}

Received 7 April 2020 • Accepted 19 June 2020

\begin{abstract}
Creativity is an important skill that will increasingly play a role in the future professional sphere, not only in arts and crafts professions but also in science, technology, engineering and mathematics (STEM) professions. It is precisely in this field that new methods and products have to be constantly developed. Therefore, the promotion of high creative potential needs to start at school. Extracurricular learning activities that prepare pupils for science competitions can also have an impact on this promotion. Since few studies have explored divergent thinking in school chemistry classes and extracurricular science competitions, this study aims to show differences in divergent thinking based on gender, parental academic background and prior participation in a science competition, using a validated test.
\end{abstract}

Keywords: $21^{\text {st }}$ century skills, creative thinking ability, creative problem solving, formal education, informal science education, open-ended problems, problem-solving skills

\section{INTRODUCTION}

Creativity is a skill that is becoming increasingly important. The World Economic Forum recently published its 'Future of Jobs' report, in which creativity is listed as the third most important job skill in 2020 (Gray, 2016). Other skills closely related to creativity, such as 'complex problem solving' and 'cognitive flexibility', are ranked as number one and number 10 . The fact that three creative skills are included in the top 10 list highlights the importance of creativity for the future. "To prepare for 2030, people should be able to think creatively, develop new products and services, new jobs, new processes and methods, new ways of thinking and living, new enterprises, new sectors, new business models and new social models", claims the Organisation for Economic Cooperation and Development (OECD) (2018). Therefore, countries should consider offering education that is in line with this, in order to develop nation's economy (Suardiman \& Kumara, 2018). In order to prepare the next generation accordingly, creativity must be promoted. To this end, the promotion of creativity as part of the school curriculum is essential. Creativity fosters the generation of new ideas and solutions to problems (Abraham, 2016). One important characteristic of creativity is the ability to think divergently (Omusonga, Indoshi, \& Achieng'Rabari, 2011). Divergent thinking is a cognitive ability of a creative person that is strongly associated with problem finding and problem solving (J. P. Guilford \& Hoepfner, 1976; Runco \& Okuda, 1988). Pupils can learn about problem awareness and problem solving in a flexible way at school, not only in artistic subjects but also in STEM subjects like chemistry. However, the often-used frontal teaching method in classical chemistry lessons is not suitable for promoting creativity (Gärtner, 1997; Kind \& Kind, 2007). Creativity can be unfolded in a certain level of freedom in the classroom (Alane Jordan Starko, 2010). Enjoying more freedom in learning in chemistry lessons not only promotes creativity but may also encourage pupils to consider a career in chemistry.

Teachers play a key role in implementing creativity in the classroom. Teaching should therefore move away from its classical recipe-like structure and more towards independent, pupil-centred methods, since these give pupils the opportunity to develop, test and revise their own ideas (Semmler \& Pietzner, 2017). Teachers need to learn to pass control to their pupils and view them less as a disruptive factor when they ask original questions, but more as an enrichment (Kettler, Lamb, Willerson, \& Mullet, 2018). 


\section{Contribution to the literature}

- No studies exist so far addressing problem discovery and divergent thinking in science competitions. This case study shows differences regarding problem discovery and divergent thinking between school pupils and science competition participants.

- No differences in divergent thinking appear between the groups regarding parental and no parental academic background within school pupils' group, as well as within science competition participants. These findings contradict with Smith and Carlsson (Smith \& Carlsson, 1985)

- Interestingly, the most creative in this study can be found in the control group and not in the group of the science competition participants.

In addition to the school as a formal learning location, children interested in science can participate in extracurricular activities such as science competitions. In preparation for such competitions, pupils work freely and independently on their projects to generate a solution to their problem in their free time. Here, divergent thinking is needed to seek solutions to the problem as widely as possible (Wirt, 2011). At Germanys most famous Young Scientist Competition (Schüler experimentieren), pupils have the opportunity to apply to the competition with their projects in the areas of work environment, biology, chemistry, geo- and space sciences, mathematics/IT, physics, and technology (Jugend forscht e.V., 2020c). This competition not only develops the joy of the subject and possible career options in science fields and an easy career entry due to the network of the sponsors, but also economic opportunities by registering a patent for particularly novel and original solution of a problem. Although divergent thinking is required in extracurricular learning activities, it has not yet been studied in any detail. Only Mund (2007) used a figural creativity test to compare the creativity of two different Young Scientist (Jugend forscht) and Music (Jugend musiziert) national Competition and the control group at school. The aim of the study presented here is to investigate the possible differences in problem discovery and divergent thinking abilities of pupils taking part in Germany's Young Scientist Competition (Schüler experimentieren) and those of pupils in German high schools that did not take part in the competition. To this end, a validated test was used. The main results regarding differences in gender, parental academic background and previous participation in a science competition are presented.

\section{THEORETICAL BACKGROUND}

Creativity is everywhere, in our work and our personal lives, but there is no unified concept of creativity. J. P. Guilford, the founder of modern creativity research, emphasized the importance of creativity and triggered a veritable trend in the United States after initiating such research in the 1950s. In the 1970s, this trend also reached Europe. Since the is no uniform definition of creativity, this paper is based on Urbans (2004) model of creativity, which is the first basic definition of this paper. He defines creativity as the ability to develop a new product that represents a solution to a previously perceived problem. In his so called 4-P-E model, he describes the entire interaction process as consisting of the factors Problem, Person, Process, Product, which are surrounded by the Environment. According to Urban, "factors of the macro-environment - socio-historical, cultural, economic and political - as well as factors of microenvironments, such as socio-economic conditions of the family, regional and local conditions, determine the reach/breadth and the existence or the recognizability of possible problems to be solved creatively" (Urban, 2004, p. 32). Problem solving is needed for creativity (Urban, 2004), and the previously perceived discovery of a problem also requires a creative person. Problem discovery is a cognitive component of a creative person, as they will have a certain problem sensitivity; they recognize problems and formulate them. Finding and solving problems is a basic requirement for creative performance (Runco \& Okuda, 1988; Wakefield, 1985). Runco and Okuda used these creative characteristics in their study and state that "problem discovery is a particularly important component in the creative process because it occurs first, and because the quality of a problem may in part determine the quality of solutions". One of their key findings was that problemfinding skills are statistically independent of problemsolving skills (Runco \& Okuda, 1988).

To solve the sensitively perceived problem, another important cognitive component of a creative person is needed, which is called divergent thinking (Urban, 1991). Thereby, the creative person solves problems by thinking broadly to generate alternate solutions (Joy Paul Guilford, 1959). Guilford was the first who defined divergent thinking. 'In divergent thinking operations we think in different directions, sometimes searching, sometimes seeking variety' (Joy Paul Guilford, 1959, p. 470). This definition is the second basic definition of this paper. In contrast to convergent thinking, where people follow a set path. Divergent thinking is an important skill of a creative person for creative thinking (J. P. Guilford \& Hoepfner, 1976), for this reason divergent thinking belongs to the important field of creativity research (Silvia et al., 2008). Various divergent thinking 
tests are available to measure creative abilities by evaluating the criteria fluency, flexibility and originality (Runco, Abdulla, Paek, Al-Jasim, \& Alsuwaidi, 2016).

The third and final basic theory of this paper is the division of creativity in various levels and its framework, which is summarized in the Four C model (Kaufman \& Beghetto, 2009). Many earlier studies define creativity as little-c or Big-C. Little-c is about the everyday creativity that almost everybody generates, for example when coming up with a creative solution to an everyday problem at work. Big-C is 'eminent creativity', or the creative work of geniuses (Kaufman \& Beghetto, 2009). The Four $\mathrm{C}$ model builds on the earlier Big-C/little- $\mathrm{C}$ model, as not all aspects of creativity, such as children's creativity at work and at play, were included in this model (Daniels, 2013). Therefore, mini-c can be understood as a form of transformative learning, which is highly significant for the individual and appears in the form of experiences, actions and insights (Daniels, 2013). In addition to mini-c, the Four $C$ model also names little- $c$, Pro-C and Big-C. Pro-C refers to professional creativity of experts, but is not overwhelmingly creative, whereas Big- $C$ has a large impact on culture (Daniels, 2013). For pupils, little-c is important in school and extracurricular activities like the Young Scientist Competition (Daniels, 2013; Alane J. Starko, 2018).

Although creativity is part of curriculum (Niedersächsisches Kultusministerium (Hrsg.), 2012, $2015,2017)$, the rigid teaching structure in which lessons are strictly planned according to the theory, elaboration and results phases (Meyer, 2002), inhibit creativity in classroom. Typical lessons are equivalent to convergent thinking, which is defined by Guilford (1959, p. 470) as information that leads "to one right answer or to a recognized best or conventional answer". Therefore, pupils who follow this thinking process are rewarded with good performance in exams, whereas the performance of divergent thinkers is neglected or punished (Cropley, 1978; Getzels \& Jackson, 1962). Many teachers have already recognized the importance of creativity, but not the importance of divergent thinking in classroom. Although the majority of teachers (94\%) in a European study on creativity in schools in the EU said that "creativity is important to be developed in schools" (Cachia \& Ferrari, 2010, p. 11), only 10\% of teachers currently believe that divergent thinking is important (Springub, Semmler, Uchinokura, \& Pietzner, 2017). They do, however, recognize that they need to be creative themselves and to think broadly in the face of today's austerity in the education sector. However, STEM subjects such as chemistry offer a great opportunity to develop pupils' problem discovery and divergent thinking ability in classroom. Therefore, teachers must break away from the often used frontal teaching method (Gärtner, 1997; Kind \& Kind, 2007) and create an appropriate environment in which pupils can work fearlessly and independently, by ensuring favourable emotional and motivational conditions that promote individual thinking processes and reward original problem solutions (Cropley, 1978). A pupilcentred method is suitable here, in which the pupils have the opportunity to develop their own ideas, to test and revise them (Semmler \& Pietzner, 2017).

Unlike in formal school settings, in junior laboratories, pupils have the opportunity to work differently and more freely. Many of these laboratories have been established in Europe over the past decades to promote interest in science (Janštová, Dvořáková, \& Jáč, 2016). As a result, non-formal learning was created by science centres and junior laboratories (Affeldt, Tolppanen, Aksela, \& Eilks, 2017; Council of Europe, 2003). Non-formal learning settings offer a big impact on pupils' learning and the development of scientific literacy (Robelen, 2011) and provides a "great opportunity to support science learning, develop competence and enhance student achievement" (Sahin, 2013 , p. 7). As long as the aims and content of activities in after-school programmes are well defined, they are a means to "foster interpersonal competence, help define life goals, and promote educational success" (Wirt, 2011, p. 48). They also foster positive interaction and relationships with peers and adults (Mahoney, Cairns, \& Farmer, 2003).

Though, participation in extracurricular activity like science competition differs between the sexes. Girls are underrepresented in science competitions, especially in domains like chemistry (Abernathy \& Vineyard, 2001; Janštová, et al., 2016; Lengfelder \& Heller, 2002). Gender is a cultural construct (Rüschenpöhler \& Markic, 2020) that differs between the countries. The cultural gender determinant may explain low participation in extracurricular activities because girls associate science with a masculine profession (Barth, Kim, Eno, \& Guadagno, 2018) and therefore cannot see themselves as scientists (Baker \& Leary, 1995; Kennedy \& Parks, 2000). Reason for that view of a scientist might be caused by stereotypes of scientists and gender stereotypes (Carli, Alawa, Lee, Zhao, \& Kim, 2016). Gender issues do not justify with the lack of interest of women, but "that people perceive women to have fewer of traits needed a good scientists" (Carli, et al., 2016, p. 246). Thus, the role of scientists is related to gender stereotypes "that frame science as masculine and women scientists as less competent" (Akl, 2012). The gender role of women is more associated with communal, but less attributed to scientists, whereas male stereotypes agree with the stereotypes of a scientist and are perceived as highly agentic (Carli, et al., 2016). In addition, pupils with low stereotypical views (Barth, et al., 2018) and positive selfconcepts are more likely to be interested in a STEM occupation (Rüschenpöhler \& Markic, 2020). Experiences in school, as well as at home or in extracurricular activities strengthen the STEM selfefficacy and interests of girls and are in no way inferior 
to their male classmates (Barth, et al., 2018). However, the self-concepts of German pupils differ between gender (Rüschenpöhler \& Markic, 2020). Boys have a stronger chemistry self- concept than girls, whereas within the group of Turkish migration background, the results are reversed. They attribute these results to stereotypes in STEM, because in they are less associated with masculinity in Turkey than in Germany (Rüschenpöhler \& Markic, 2020). Although girls of Turkish migration background have a higher chemistry self-concept, this is not reflected in vocational training or studies at university. Vocational training or commencement of studies is related to social background and less to scientific skills and schoolleaving qualifications (Bundesministerium für Bildung und Forschung, 2008). The German education system is particularly important here, primarily disadvantaging children from socio-economic disadvantaged families (BMBF, 2019), and female migrant children (Farrokhzad, 2015). Overall, the total number of women in STEM professions in Germany is low. Only $28 \%$ freshman at university in STEM subjects are women (OECD, 2017) and accounted for only $15.4 \%$ of STEM jobs in 2018 (Agentur für Arbeit, 2019). The low participation of girls in scientific extracurricular activities and later in STEM professions depends on gender stereotypes, as well as stereotypes of scientists, self-concept and parental home. Especially parents are the most important influencers in the development of children's interests and strengthen their self-confidence. With regard to Germany and the parental socialization of the science-related job expectations of their children, it can be seen that the influence of parents who attach high or low priority to natural science, does not affect the science-related job expectations of their children (Taskinen, 2010). Moreover, regardless of children's gender, parent's priority attributed to the natural sciences by the parents does not affect on children's science-related job expectations. However, there are differences in sciencerelated job expectations regarding socio-economic status of parental home. For example, children with sciencerelated job expectations are more likely to live in parental homes in which at least one parent is pursuing an academic science-related profession (Taskinen, 2010). In addition to parents, teachers also have an influence.

Instructions for teachers recommend to improve the classroom atmosphere "that build a climate that encourages students to support one another's academic and career interests regardless of gender" (Barth, et al., 2018). In addition, teachers should strengthen their pupils' self-concept relating to STEM subjects (OECD, 2018; Springub, et al., 2017). If this is not done, the process of socialization means that girls will often be excluded from gender atypical professions as early as the ages of six to eight years old (Kirsten, 2007), which supports the circumscription and compromise theory of Gottfredson (1981, 1996). Children start thinking about career aspirations and occupation of gender stereotypes as early as the age of two and a half and five years to elementary school age (Barth, et al., 2018), when they also start to exclude occupations that they perceive as gender atypical (Gottfredson, 1981). These gender atypical differences in preferences will not change during the long process of career choice from early elementary school through high school (Gottfredson, 1981), only at college age do students become aware of the professional stereotypes (Barth, et al., 2018). The latter in particular can be good predictor of interest in STEM, increases with age in girls (Barth, et al., 2018) and should therefore be encouraged earlier in school life. A German coaching program to strengthen girls in STEM occupations recommend that girls benefit from a monoeducation in experimentation meanwhile they show more actively and initiative because they have to adapt less to gender stereotypes (Oerke \& Eigenstetter, 2018) and provide themselves in direct competition with the boys (Schuster, Sülzle, Winker, \& Wolffram, 2014). There are differences in group composition in mixed sex groups, both in school and in extracurricular activities. Webb (1984) showed that a balanced female to male ratio in groups equated to a balance in achievement and interactions, whereas groups with a majority of boys tended to ignore the girls and achieve better learning outcomes themselves. Boys are therefore not only more dominant in groups, but also more effective in competitive environments than girls (Gneezy, Niederle, \& Rustichini, 2003). Boys participate more often in competitive activities (Gneezy, Leonard, \& List, 2009, p. 1637), and their competitiveness is often named as an important reason for participating in chemistry and physics competitions (Janštová, et al., 2016).

In the present case study, the focus is on science competitions and addresses the question of possible gender differences, as well as parental academic background and previous participation in a science competition regarding problem discovery and divergent thinking. Therefore, data was collected on Germany's most famous Youth Science competition, Jugend forscht, which was established in 1965 to foster an interest in science in adolescents. It is supported by the German chancellor and president, as well as by 16 Ministries of Education and the Arts and many large companies (Jugend forscht e.V., 2020b, 2020d, 2020e). Participants aged 10 to 14 take part in the junior category, Schüler experimentieren, and the older participants aged 15 to 21 take part in the Jugend forscht category. Participants who have worked on a project in one of the seven areas of work environment, biology, chemistry, geo- and space sciences, mathematics/IT, physics, and technology present their results to a jury in the regional competitions (Jugend forscht e.V., 2020c). The winners of the regional competitions go on to participate in the federal contest; for Schüler experimentieren participants, this is the final level. Winners of the federal competition at the Jugend 
Table 1. Questionnaires by Wallach and Kogan (1965) and Wakefield (1985) Adapted presented problem test (DT) by Wallach and Kogan (1965)

\begin{tabular}{lll}
\hline Instances & "Name all the round things you can think of", & "Choose a category, then list instances of \\
& "Name all the things you can think of that will make a noise", & "Name all the things you can think of that move on wheels". \\
Alternate uses & "Tell me all the different ways you could use a knife", & "Choose an object then list uses for it". \\
"Tell me all the different ways you could use a chair". & "Tell me all the ways in which a potato and a carrot are alike", \\
Similarities & "Tell me all the ways in which a cat and a mouse are alike", & "Choose two objects that are alike, then list \\
& "Tell me all the ways in which a radio and a telephone are alike". & your ideas of how the objects are similar". \\
\hline
\end{tabular}

forscht level are allowed to participate in the national competition (third level).

The divergent thinking abilities of pupils in science education have not been adequately studied, as only one study of creativity in extracurricular learning activities like Jugend forscht exists (Mund, 2007). Isolated studies of physics classes in Asian countries such as China ( $\mathrm{Hu} \&$ Adey, 2002), Korea (Jo, 2009) and Malaysia (Mohtar, Halim, \& Iksan, 2016), as well as in African country like Kenya (Omusonga et al., 2011) and one European country like Greece (Diakidoy \& Constantinou, 2001), have been conducted.

Divergent thinking in science, especially in chemistry education and extracurricular activities like science competitions, has been little studied so far. This research gap will be explored with the following research question:

Do the divergent thinking abilities of pupils taking part in Germany's Young Scientist Competition (Schüler experimentieren) differ from high school pupils of the same age, taking into account gender, previous participation and the academic background of the parents?

\section{METHOD}

The present survey is a case study because of the small sample size. However, also case studies can contribute to the field of research. For example, they can be used to generate hypotheses or to explore a new field of research (Flyvbjerg, 2006). A small sample size is a "special feature of small-n research" and offer more opportunities to work in a research field (Ragin, 1992, p. 225 quoted after Flyvbjerg, 2006). Case studies are needed in a discipline to provide thoroughly described examples; without these examples, a discipline is in danger to be ineffective. In our study we took a look on the example of pupils' divergent thinking skills.

In our study, data were collected using two adapted questionnaires from a study by Runco and Okuda (1988). The first questionnaire is a divergent thinking test by Wallach and Kogan (1965), which contains three standards, or 'presented problem' items: instances, alternate uses and similarities. The second questionnaire is a problem discovery test, which was adapted from
Wakefield (1985) in Runco and Okuda's (1988) study, for each of these items. In this test, participants need to recognize a problem, define it and develop their own solutions. An overview of all the tasks and items in the divergent thinking and problem discovery tests is given in Table 1.

The divergent thinking and problem discovery tests were evaluated according to three creativity criteria: fluency, flexibility and originality. Fluency is the number of distinct ideas as described by Runco (1986). Flexibility is the number of categories from which the ideas originated. For this, the responses of each participant were associated with a category on the Torrance (1966) category list. This list was extended with extra categories if an answer could not be assigned to an existing category and if several terms fitted into this new category. Originality describes the statistical rarity of an answer. To evaluate the criterion of originality, a table is drawn up with all answers of surveyed learning location and percentage of rarity was calculated. According to Runco and Albert (1985), each answer is awarded points depending on the frequency with which it is given. Participants whose answers are unique receive three points, answers that are mentioned by fewer than $2.5 \%$ of the respondents are awarded two points, answers that are mentioned by $2.51-4.99 \%$ of the respondents are awarded one point, and answers that are mentioned by more than $5 \%$ of the respondents receive no points. Originality was only measured in Wallach and Kogan's (1965) divergent thinking test, and not in Wakefield's (1985) problem discovery test, because the answers cannot be compared due to the individually discovered problems. Therefore, only the criteria of fluency and flexibility were used to measure Wakefield's test. Wakefield's problem discovery test and Wallach \& Kogan's divergent thinking test were developed for children. The latter is based on Guilford's (1959) proposed theoretical model. The test has been common ever since used in creativity research and carried out in a unique test atmosphere (Chan et al., 2001; Cheung \& Lau, 2010; Lau \& Cheung, 2010a, 2010b; Alane Jordan Starko, 2010). In addition to Chinese studies on creativity development and gender differences among school children in Hong Kong, the test was also used for the intercultural examination of task specificity of creativity in France and China (Storme et al., 2017), as well as for 
measuring the learning effect of a musical instrument on creative ability in middle school (Fletcher, 2019). Besides of that, the instrument was used in conjunction with Wakefield's problem-finding test and used in the present study, since problem-finding is statistically independent of problem solving (divergent thinking) (Runco \& Okuda, 1988). Both tests meets the quality criterion reliability, which has been demonstrated using American data (Acar \& Runco, 2012; Cropley \& Maslany, 1969; Runco \& Okuda, 1988). This research instrument can be used in the context of Germany, since the quality criterion was carried out in the USA and both countries can be defined as western industrial country. Therefore, no cultural differences exist, and it is not necessary to adapt the instruments for Germany.

The test questions were entered into an app called Actionbound, which is free and supported by the German Federal Agency for Civic Education. Participants can use the keyboard or click on the corresponding field in the multiple-choice test to answer questions. A digital collection method like Actionbound allows anonymous surveys to be carried out that only require a smartphone with internet access. Fast data transfer is supported by the app.

Before the data could be collected from the underage participants, permission had to be obtained in advance from the provincial school authorities in order to conduct the survey in schools in Lower Saxony. After approval had been obtained, the respective chemistry teachers of the surveyed classes sent parents a leaflet and a declaration of consent. The leaflet informed the parents about the study's approach and asked them to install the Actionbound app on their child's devices and to sign the declaration of consent. Those pupils whose parents did so were able to participate in the survey. Regarding the Young Scientist Competition, contact was made with the competition directors in the respective federal states prior to the survey, and they forwarded the parents' letters to the participants along with the consent form. In the event of a positive response, the parents' forms were recorded both electronically by email and in analogue form. The survey was conducted after the jury's evaluation of the projects and selection of the winner.

\section{PILOT STUDY}

The pilot study was carried out to test the technical implementation with the app and the feasibility for the pupils. For this, the instruments of the main study have been used. The pilot study was conducted in January and February 2018 in comprehensive schools. Prior to this, the pupils received a declaration of consent to be signed by their parents and a letter explaining the exact procedure. Pupils were asked to download the Actionbound app on their mobile phone prior to the interview so that the 90-minute chemistry lesson in which the survey took place.
The test instrument also first included the figural circle test by Torrance (1966), in addition to the two tests by Wallach and Kogan (1965) and Wakefield (1985). In this test, pupils are asked to draw circles around figures/symbols and to draw as many as possible. However, this took too much time, so the drawing test was taken out in the main study. All the test results were entered into the app and could be downloaded afterwards from the author in the Actionbound portal.

\section{MAIN STUDY}

The Young Scientist Competition is divided into two age groups: the younger Schüler experimentieren participants aged up to 14 years and the older Jugend forscht participants aged 15 to 21 years. This Young Scientist Competition is very important for Germany, because it is the largest and most respected competition for science in Germany, which is supported by industry like main sponsors such as Fraunhofer, Helmholtz, Max Planck Gesellschaft and Fonds der chemischen Industrie (Chemical industry fund) and politics such as the 16 Ministries of Education and the Arts or the patron which is the president of Federal Republic of Germany (Jugend forscht e.V., 2020b, 2020d, 2020e). The winner of the "Chancellors prize for the most original work" of the older competition level Jugend forscht in national competition will be invited by the chancellor to the Federal Chancellery and honoured by a separate award (Jugend forscht e.V., 2019). These competitions focus on promotion young scientists for scientific professions. Some projects have already registered a patent for their creative results. For many young scientists, participating in a competition is the start of a promising career and a milestone in a personal development or groundbreaking research or multi-million dollar entrepreneurial careers (Jugend forscht e.V., 2020a).

This study investigates differences in divergent thinking and problem discovery skills in high school pupils and participants of the younger category of Young Scientist Competition (Schüler experimentieren), based on gender, parental academic background and previous participation in science competitions. Data collection was conducted in 2018 at the federal competition level of the Schüler experimentieren in a total of four German federal states in North-West Germany: Oldenburg (Lower Saxony), Hamburg (city state), Essen (North Rhine Westphalia) and Kiel (SchleswigHolstein). Prior to the survey, consent was obtained from the parents for minor pupils. A parental leaflet and a declaration of consent was handed out in advance by the competition leaders and the teachers, with the request to return the consent form by mail before the survey started. The parental leaflet also requested that pupils were asked to bring a smartphone for the survey, on which the Actionbound app had already been installed. The questionnaires were stored in this app and 
Table 2. Sample of main study

\begin{tabular}{lcc}
\hline & School & $\begin{array}{c}\text { Schüler } \\
\text { experimentieren }\end{array}$ \\
\hline Female & 35 & 12 \\
Male & 19 & 21 \\
n/a & 3 & 1 \\
\hline Previous participation & 5 & 9 \\
No previous participation & 52 & 25 \\
\hline Parental academic background & 29 & 23 \\
No parental academic background & 14 & 5 \\
n/a & 14 & 6 \\
\hline
\end{tabular}

were accessed by the respondents using a QR code. After a short personal instruction on-site by the authors, based on Runco and Albert (1985)'s explanation, the participants received this $\mathrm{QR}$ code. The participants were asked to give all the answers that came to their minds. If they could not think of any more, they were told to click on 'continue' in the app. There was no time limit, as this is more likely to be associated with convergent thinking. This creates a relaxed atmosphere and gives the respondents the opportunity to really name all of the answers that come to their minds (Acar \& Runco, 2012). The test was also designed as a game, and the pupils were told that the survey would not affect the outcome of the competition or their marks in school. Participants were very confident about using their smartphone and the app, although many were using the latter for the first time. Only some younger Schüler experimentieren participants had some problems with spelling and entering their answers.

To make differences in divergent thinking and problem discovery between Schüler experimentieren participants and high school pupils visible, based on gender, parental academic background and previous participation in science competitions, the Mann-Whitney $\mathrm{U}$ test has to be used due to the small sample size. It was used instead of the t-test for independent samples because the requirements for smaller samples are more favourable. For example, the data do not need to be normally distributed, and the variables only have to be ordinally scaled (Schwarz, 2020).

For this, the average values for each criterion (originality, fluency and flexibility) were examined. In some cases, the sample size is less than 30 , so the exact significance was used. In addition, the effect size was calculated according to Cohen (1992) to indicate the strength of the significance. A weak effect is present at $r$ $=0.10$, a medium effect at $\mathrm{r}=0.30$ and a strong effect at $\mathrm{r}$ $=0.50$.

\section{DESCRIPTION OF THE SAMPLE}

The study was conducted with pupils from four Gymnasium schools in the Weser-Ems area, Lower Saxony. A Gymnasium is a secondary school for pupils with high cognitive abilities. For that, the authors of the present study conducted the survey at school, who were chosen at random and to generate the status quo at ordinary German schools. Pupils aged 12 to 14 took part in the study, which equals the age of the participants in the Schüler experimentieren. To investigate differences between school pupils who did not take part in the science competition and pupils who did (Schüler experimentieren participants), only school pupils aged up to 14 were included in the study. The focus of this case study is not on the school, but rather on the extracurricular activities such as Youth Science competition like Schüler experimentieren. The school data are only used to show a possible difference in the creativity potential of the two groups and in order to show a possible significant trend, which pupils take advantage of the offer of Schüler experimentieren. The Schüler experimentieren sample included 34 participants aged 10 to age 14 (12 female, 21 male and $1 \mathrm{n} / \mathrm{a}$ ) in the federal science competition. The data were collected in on federal competitions in Oldenburg (Lower Saxony), Hamburg (city state), Essen (North Rhine Westphalia) and Kiel (Schleswig-Holstein).

\section{RESULTS}

In this section, results for the participants in the Schüler experimentieren are compared with the results for school pupils of the same age.

\section{Parental Academic Background}

No differences in divergent thinking and problem discovery were found between school pupils whose parents did or did not have an academic background. This also applies to the participants in the Schüler experimentieren: no significant difference exists between participants in the Schüler experimentieren whose parents did or did not have an academic background.

Differences occurred when looking at the pupils in both groups who have parents with an academic background. School pupils then performed better in both tests than participants in the Schüler experimentieren. School pupils scored higher for originality, fluency and flexibility than Schüler experimentieren participants in the divergent thinking test (see Table 3). In the problem discovery test, school pupils had far better flexibility and somewhat better fluency.

No differences were measurable between school pupils and Schüler experimentieren participants with no parental academic background. 
Table 3. Differences between school pupils and Schüler experimentieren participants with parents with an academic background

\begin{tabular}{lcccccc}
\hline Test & Criterion & $\begin{array}{c}\text { Mean value, } \\
\text { school pupils }\end{array}$ & $\begin{array}{c}\text { Mean value, Schüler } \\
\text { experimentieren participants }\end{array}$ & $\mathrm{Z}$ & $\mathrm{p}$ & $\mathrm{r}$ \\
\hline Divergent thinking & Originality & 5.02 & 4.09 & 5.05 & -2.460 & 0.014 \\
(DT) & Fluency & 5.76 & 3.39 & -2.055 & 0.040 & 0.341 \\
& Flexibility & 3.72 & -2.019 & 0.043 & 0.285 \\
Problem discovery & Fluency & 4.82 & 2.97 & -2.595 & 0.009 & 0.360 \\
(PD) & Flexibility & 3.03 & 2.17 & -2.607 & 0.009 & 0.362 \\
\hline
\end{tabular}

Table 4. Differences between school pupils and Schüler experimentieren participants with no experience in a science competition

\begin{tabular}{lcccccc}
\hline Test & Criterion & $\begin{array}{c}\text { Mean value, } \\
\text { school pupils }\end{array}$ & $\begin{array}{c}\text { Mean value, Schüler } \\
\text { experimentieren participants }\end{array}$ & $\mathrm{Z}$ & $\mathrm{p}$ & $\mathrm{r}$ \\
\hline Divergent thinking & Originality & 4.17 & 3.55 & 4.58 & -2.329 & 0.020 \\
(DT) & Fluency & 5.42 & 3.10 & -2.862 & 0.004 & 0.265 \\
& Flexibility & 3.59 & -2.808 & 0.005 & 0.326 \\
\hline Problem discovery & Fluency & 4.58 & 2.88 & -2.549 & 0.011 & 0.290 \\
(PD) & Flexibility & 2.74 & 2.28 & -2.043 & 0.041 & 0.233 \\
\hline
\end{tabular}

Table 5. Differences between school pupils with prior experience and Schüler experimentieren participants with no prior experience in a science competition

\begin{tabular}{lcccccc}
\hline Test & Criterion & $\begin{array}{c}\text { Mean value, } \\
\text { school pupils }\end{array}$ & $\begin{array}{c}\text { Mean value, Schüler } \\
\text { experimentieren participants }\end{array}$ & $\mathrm{Z}$ & $\mathrm{p}$ & $\mathrm{r}$ \\
\hline Divergent thinking & Originality & 5.51 & 3.55 & 4.58 & -2.201 & 0.027 \\
(DT) & Fluency & 6.76 & 3.10 & -2.338 & 0.016 & 0.402 \\
& Flexibility & 3.78 & -2.060 & 0.037 & 0.427 \\
\hline Problem discovery & Fluency & 6.87 & 2.88 & -2.458 & 0.011 & 0.449 \\
(PD) & Flexibility & 3.80 & 2.28 & -2.390 & 0.016 & 0.436 \\
\hline
\end{tabular}

\section{Previous Participation in a Science Competition}

Within the school pupils' sample, no significant differences were found for all criteria in the divergent thinking test between pupils who had previously participated in a science competition one to three times and pupils who had not previously participated in a science competition. In the problem discovery test, school pupils who had previously participated in a science competition performed better in the mean value of flexibility (mean value for school pupils with previous participation $=3.80$, mean value for school pupils with no prior participation $=2.74, \mathrm{U}=58.000, \mathrm{Z}=-2.042, \mathrm{p}=$ $0.041, \mathrm{r}=0.270$ ).

Regarding possible differences between Schüler experimentieren participants with previous or no prior participation in a science competition, no significant differences in all the criteria of the divergent thinking and problem discovery tests could be found.

Comparing the two groups, participation in a science competition seems to have an influence on flexibility. School pupils who had already participated in a science competition one to three times had a higher value for flexibility in the problem discovery test than Schüler experimentieren participants who had also participated in a science competition one to three times (mean value for school pupils $=3.80$, mean value for Schüler experimentieren participants $=2.15, \mathrm{U}=6.500, \mathrm{Z}=-2.140$, $\mathrm{p}=0.029, \mathrm{r}=0.572)$.
When investigating participants in both groups that had never participated in a competition, school pupils performed better in all the criteria of the divergent thinking and problem discovery tests compared to Schüler experimentieren participants who took part in a science competition for the first time (see Table 4).

School pupils with experience in a science competition also showed a significant difference in the mean value for all items in the divergent thinking and problem discovery tests compared with Schüler experimentieren participants who took part in a science competition for the first time (see Table 5).

Comparing the reverse case regarding differences between school pupils with no prior experience in a science competition and Schüler experimentieren participants with previous experience in a science competition, no significant differences in divergent thinking and problem discovery could be measured.

\section{Gender Differences}

In this section, differences between girls and boys within the respective groups are first investigated, followed by the differences between girls in both groups and between boys in both groups.

Girls in the school pupil group scored better in fluency (mean value for girls $=2.85$, mean value for boys $=2.79, \mathrm{U}=227.500, \mathrm{Z}=-1.905, \mathrm{p}=0.057, \mathrm{r}=0.259$ ) than boys in the problem discovery test. This is in contrast to 
Table 6. Differences between girls from the school pupils and Schüler experimentieren groups

\begin{tabular}{lcccccc}
\hline Test & Criterion & $\begin{array}{c}\text { Mean value, } \\
\text { school pupils }\end{array}$ & $\begin{array}{c}\text { Mean value, Schüler } \\
\text { experimentieren participants }\end{array}$ & $\mathrm{Z}$ & $\mathrm{p}$ & $\mathrm{r}$ \\
\hline Divergent thinking & Originality & 3.91 & 2.27 & -2.233 & 0.026 & 0.326 \\
(DT) & Fluency & 5.58 & 4.07 & -2.563 & 0.010 & 0.374 \\
& Flexibility & 3.64 & 2.82 & -2.774 & 0.006 & 0.405 \\
\hline Problem discovery & Fluency & 5.17 & 2.69 & -2.738 & 0.006 & 0.399 \\
(PD) & Flexibility & 2.85 & 2.11 & -2.319 & 0.020 & 0.338 \\
\hline
\end{tabular}

Table 7. Differences between girls in the school pupils group and boys in the Schüler experimentieren group

\begin{tabular}{lcccccc}
\hline Test & Criterion & $\begin{array}{c}\text { Mean value, } \\
\text { school pupils }\end{array}$ & $\begin{array}{c}\text { Mean value, Schüler } \\
\text { experimentieren participants }\end{array}$ & $\mathrm{Z}$ & $\mathrm{p}$ & $\mathrm{r}$ \\
\hline Divergent thinking & Originality & 3.91 & 3.46 & -2.015 & 0.044 & 0.269 \\
(DT) & Fluency & 5.58 & 4.34 & -2.912 & 0.004 & 0.389 \\
& Flexibility & 3.64 & 3.10 & -2.686 & 0.007 & 0.359 \\
\hline Problem discovery & Fluency & 5.17 & 3.19 & -2.848 & 0.004 & 0.381 \\
(PD) & Flexibility & 2.85 & 2.29 & -2.734 & 0.006 \\
\hline
\end{tabular}

the Schüler experimentieren participants, where the U test showed no differences with respect to gender in both tests.

When investigating differences between girls in the school pupils group and the Schüler experimentieren participants group, the results show that girls in the pupils group performed better in all criteria of both tests than girls in the Schüler experimentieren group (see Table 6).

Looking at the boys, no significant differences in both tests were measurable between the school pupils and Schüler experimentieren participants. Also, boys from the school pupils group and girls from the Schüler experimentieren group showed no significant differences in the U test.

However, the results do show a significant difference between girls in the school pupils group and boys in the Schüler experimentieren group. In all criteria (fluency, flexibility and originality) of the divergent thinking test, the girls performed better than the boys. In the problem discovery test, girls in the school pupils group also performed better in all criteria (fluency and flexibility) than boys in the Schüler experimentieren group (see Table 7).

\section{DISCUSSION AND CONCLUSION}

This case study shows that there are gender differences between school pupils and participants in the Schüler experimentieren: girls in the school pupils' group are better in divergent thinking and problem discovery than girls and boys in the Schüler experimentieren group. Following this train of thought, female school pupils are more creative than female and male participants in the Schüler experimentieren group, but they do not necessarily participate in science competitions. One possible reason for this finding might be the selection criteria of the teachers, as they are the ones who usually encourage pupils to participate. It seems that it is not creative abilities, but rather the pupils' marks, that are crucial in identifying them as possible Schüler experimentieren participants. This is also shown in a study by Descalc,o and Olivereira (2018), in which teachers pre-selected the best-performing pupils in class for a national science competition. Teachers' nomination processes favour male pupils, due to their competences in technical subjects. The role of the teacher therefore plays an important role in the selection and promotion of female pupils in school as well as in extracurricular learning activities, such as science competitions. (Lengfelder \& Heller, 2002) It is also noticeable that only a few girls participate in the Schüler experimentieren, although this result does correspond with the results of other studies into science competitions (Lengfelder \& Heller, 2002; Verna \& Feng, 2002), except biology competition (Steegh, Höffler, Keller, \& Parchmann, 2019). Steegh et al. (2019) see a connection between participation in science competitions and good performance in mathematics and science subjects at school, as other results from studies in the United States and in several other countries confirm (Steegh, et al., 2019). However, this finding contradicts with results from Finland, where girls perform better than boys in science subjects at school (OECD, 2016). Even so, the number of female participants in science competitions is just as low in Finland as in other countries (Steegh, et al., 2019). Following from this, the proportion of female participants does not match the proportion of talented girls, so the selection process needs to change, as it is currently based on teachers' judgments alone (Lengfelder \& Heller, 2002). Another possible reason why girls are less likely to be selected by teachers is because of the characteristics of a creative person, which are perceived by teachers as negative and disturbing; they mostly prefer character traits like "conformity and unquestioning acceptance of authority" (Westby \& Dawson, 1995). Although teachers see creative pupils as an enrichment in the classroom, they prefer the character traits of non-creative people (Westby \& Dawson, 1995). The main character traits of a creative person are, among 
others, "independence of judgment, autonomy, intuition, self-confidence $(\ldots)$ to accommodate apparently opposite or conflicting traits in one's selfconcept" (Barron \& Harrington, 1981, p. 15). Conformity and gender roles inhibit creativity in girls and boys, and creative character traits like independent and positive self-assessment are more likely to be attributed to boys (Cropley, 1978; Kämmerer, 2000; Steegh, et al., 2019). In contrast, girls with creative character traits are perceived by teachers as "bossy" and "troublemakers", because they oppose the "good girl" image, which is imposed on them by society (Wirt, 2011, p. 59). The formation of this stereotype starts in primary school, where "teachers tend to praise boys for the quality of work and girls for form and neatness" (Tobin \& Garnett, 1987, p. 91). Through socialization of gender stereotypes and scientist stereotypes, which a connected with masculine stereotypes, girls identify less with scientists and therefore consider less often participation in a science competition.

Therefore, further studies should carry out conditions of female pupils and teachers influence on the selection of pupils for participation in the Young Scientist Competition, and which selection criteria the teachers use. In addition to their selection criteria, their own creative personality should also be examined in future studies to show if there is a connection between creative teacher personality and selection criteria. "Even if teachers have a positive attitude towards creativity, this can only be effective if they show themselves as a creative personality" (Springub, et al., 2017, p. 43). Furthermore, female teachers "have a higher approval regarding the positive influence of creative teaching on the creativity of students", "show a significantly higher belief that creativity promotes success", and "rated activities associated with models and laws as more creative than male teachers" (Springub, et al., 2017, p. 47, $48,50)$. In addition, children with an increased ability to think divergently can develop this ability the best with teachers who also have a strong inclination towards divergent thinking (Cropley, 1978).

Possibly, German teachers may prefer pupils that are good at science, similar to the results of the study of Descalço and Olivereira (2018). Pupils with good marks are interested in performing well and are often accustomed to following the teachers' convergent paths from their own lessons. In addition, these pupils also follow the rather convergent way of coming up with solutions when working on a project. This goes hand in hand with the characteristics that teachers prefer in pupils, such as diligence and aspiration, openmindedness to other people's ideas, and respect for authority (Cropley, 1978). Topics for the research projects in the Schüler experimentieren often involve real scientific phenomena in the pupils' environments, such as "What caused the different flame colour in the magic candles", or "What is the best possible mixing ratio between water and soap to form a stable soap bubble?" These are often topics for which solution can be found on the internet, and the research process can be steered in a convergent direction. If the participants are overly influenced by a knowledgeable teacher, especially if the participants in the Schüler experimentieren are still very young, the path to the solution will be convergent. This convergent problem-solving path is accompanied by the third type of motivation, which is 'extrinsic reward' (Cooper \& Jayatilaka, 2006). Pupils are promised a reward, usually good marks, when they participate in an extracurricular activity (Wirt, 2011). With this type of motivation, the problem is not considered in great depth, and the pupil has no intrinsic interest in solving the problem (Cooper \& Jayatilaka, 2006). This pupil will only solve compulsory tasks to get the reward, which does not stimulate their individual creativity (Cooper \& Jayatilaka, 2006). Motivational factors play a major role in Campbell and Feng's (2010) finding, which is that there is a lack of motivation among the less successful competition participants. In addition, extrinsic motivation has a more negative impact on the creativity of girls than of boys (Baer, 2013). Rather intrinsic motivation is essential for creativity (Amabile, 1983), which leads to the best academic outcomes and promotes joy (Orvis, Sturges, Tysinger, Riggins, \& Landge, 2018; Alane J. Starko, 2018). This joy is certainly a reason why the participation in a mathematics and science competition has a positive influence on pupils' interests in science and mathematics and their "attitudes, and are offered during the critical life phase in which adolescents make course and, ultimately, career decisions" (Steegh et al., 2019, p. 5). In addition, participation in extracurricular activities (Barth, et al., 2018) such as mathematics or science competition increases the likelihood that participants will later consider a career in science (Steegh et al., 2019). These activities offer great potential, especially for girls, whose interest in STEM depends not only on ability but also on self-efficacy (Bandura, Barbaranelli, Caprara, \& Pastorelli, 2001). Therefore, young girls should receive a scientific education that positively influences their selfconcept with regard to a later career choice in the natural sciences (Miller, Slawinski Blessing, \& Schwartz, 2006; Oerke \& Eigenstetter, 2018). Also, pupils with migration background and from socio-economic disadvantaged homes should be increasingly enthusiastic about extracurricular activities. Through the joy in creative scientific and the dismantling of gender stereotypes, the mentioned groups could strengthen the scientific interest and self-concept here. In best case, they arouse curiosity about a scientific profession. However, the group constellation should be taken into account.

As this study show, it is striking that a lot of Schüler experimentieren participants have parents with an academic background, which makes the competition elitist (see Table 3). This trend is also evident in 
mathematics and science competition participants, who mostly come from families with a high educational status, thereby using intellectual resources and receiving a high level of support (Stang, Urhahne, Nick, \& Parchmann, 2014). Also, in other cultural environments such as in Taiwan, parents with an academic background encourage their children to participate in science competitions (Wu \& Chen, 1999).

The relationship between the academic background of parents and divergent thinking was examined in this study because, until now, only one study on creativity and parental academic background could be identified (Smith \& Carlsson, 1985). Smith and Carlsson (1985) found a connection in form of a peak between parental academic background and creativity in 10 -11-years old Their study contradicts with the current one, because parental academic background has no influence on the divergent thinking abilities of the participants of this study within participants in the Schüler experimentieren and the school pupils group. But comparing participants from school and Junior laboratories with parental academic background, school pupils displayed more divergent thinking and performed better in problem detection than Schüler experimentieren participants. A possible reason may lie in the selection criteria of the teachers, who seem to prefer uncreative pupils with an academic home background, possibly because of their more obedient character traits and with the underlying assumption that they will get help from their parents. In addition, it may be the case that parents with a scientific academic background, encourage their children to science competitions, are too converged with their scientific knowledge, so that the creative ability of divergent thinking cannot be developed. The data show that the divergent thinking abilities of Schüler experimentieren participants do not develop if they participate in science competitions more often. One possible reason is the already discussed aspect that the younger pupils, in effect, work more or less on a convergent problem solution. What is striking, however, is that some pupils who have never participated in Schüler experimentieren think more divergently than the Schüler experimentieren participants. This again reflects the results that the more creative pupils do not take part in Schüler experimentieren. Whether this is also related to the selection criteria of the teachers must be clarified in a further study. In addition, this case study shows a tendency of creative potential of the investigated extracurricular activity and should be considered due to the small number of participants in a larger sample. As the data for the science competition participants come from four German federal states and those of the control group only from Lower Saxony, it may be that a divergent thinking difference exists between the federal states.

\section{ACKNOWLEDGEMENTS}

We would like to thank the board and competition management team of Jugend forscht e.V. for the opportunity to carry out this study on their competitions, as well as all cooperating teachers who made it possible to collect data in the control group.

\section{REFERENCES}

Abernathy, T. V., \& Vineyard, R. N. (2001). Academic competitions in science: What are the rewards for students? The Clearing House, 74(5), 269-276. https:/ / doi.org/10.1080/00098650109599206

Abraham, A. (2016). Gender and creativity: An overview of psychological and neuroscientific literature. Brain imaging and behavior, 10(2), 609-618. https:/ / doi.org/10.1007/s11682-015-9410-8

Acar, S., \& Runco, M. A. (2012). Chapter 6 - Creative Abilities: Divergent Thinking. In M. D. Mumford (Ed.), Handbook of Organizational Creativity (pp. 115139). San Diego: Academic Press. https:/ / doi.org/ 10.1016/B978-0-12-374714-3.00006-9

Affeldt, F., Tolppanen, S., Aksela, M., \& Eilks, I. (2017). The potential of the non-formal educational sector for supporting chemistry learning and sustainability education for all students-a joint perspective from two cases in Finland and Germany. Chemistry Education Research and Practice, 18(1), 13-25. https:/ / doi.org/10.1039/C6RP00212A

Agentur für Arbeit. (2019). Blickpunkt Arbeitsmarkt: MINT-Berufe. [Emphasis on the job market: STEM professions]. Retrieved from https://statistik. arbeitsagentur.de/Statischer-Content/Arbeits marktberichte/Berufe/generische-Publikationen/ Broschuere-MINT.pdf

Akl, A. (2012). Stereotypes deter woman from becoming scientists. Retrieved from https://www.voanews. com/usa/stereotypes-deter-women-becomingscientists

Amabile, T. M. (1983). The social psychology of creativity: A componential conceptualization. Journal of personality and social psychology, 45(2), 357. https:/ / doi.org/10.1037/0022-3514.45.2.357

Baer, J. (2013). Teaching for Creativity: Domains and Divergent Thinking, Intrinsic Motivation and Evaluation: Springer Science \& Business Media. https:/ / doi.org/10.1007/978-1-4614-5185-3_13

Baker, D., \& Leary, R. (1995). Letting girls speak out about science. Journal of research in science teaching, 32(1), 3-27. https://doi.org/10.1002/tea.3660320 104

Bandura, A., Barbaranelli, C., Caprara, G. V., \& Pastorelli, C. (2001). Self-Efficacy Beliefs as Shapers of Children's Aspirations and Career Trajectories. 
Child Development, 72(1), 187-206. https:/ / doi.org/ 10.1111/1467-8624.00273

Barron, F., \& Harrington, D. M. (1981). Creativity, intelligence, and personality. Annual review of psychology, 32(1), 439-476. https:// doi.org/10.1146 /annurev.ps.32.020181.002255

Barth, J. M., Kim, H., Eno, C. A., \& Guadagno, R. E. (2018). Matching Abilities to Careers for Others and Self: Do Gender Stereotypes Matter to Students in Advanced Math and Science Classes? Sex Roles, 79(1), 83-97. https:// doi.org/10.1007/s11199-017$0857-5$

BMBF. (2019). Bildung auf einen Blick 2019 - OECD Indikatoren. Retrieved from https://www.bmbf. de/files/6001821mw.pdf

Bundesministerium für Bildung und Forschung. (2008). Studiensituation und studentische Orientierungen. 10. Studierendensurvey an Universitäten und Fachhochschulen. [Study situation and student orientations. 10. student survey at universities and technical colleges.]. Bonn, Berlin. Retrieved from https://www.ssoar.info/ssoar/handle/document /23637

Cachia, R., \& Ferrari, A. (2010). Creativity in Schools: A Survey of Teachers in Europe. European Commission, Joint Research Centre. Institute for Prospective Technological Studies. Retrieved from https:/ / publications.jrc.ec.europa.eu/repository/ bitstream/JRC59232/jrc59232.pdf

Campbell, J. R., \& Feng, A. X. (2010). Comparing adult productivity of American mathematics, chemistry, and physics olympians with Terman's longitudinal study. Roeper Review, 33(1), 18-25. https:/ / doi.org/10.1080/02783193.2011.530203

Carli, L. L., Alawa, L., Lee, Y., Zhao, B., \& Kim, E. (2016). Stereotypes about gender and science: Women $\neq$ scientists. Psychology of Women Quarterly, 40(2), 244260. https:/ / doi.org/10.1177/0361684315622645

Chan, D. W., Cheung, P.-C., Lau, S., Wu, W. Y. H., Kwong, J. M. L., \& Li, W.-L. (2001). Assessing ideational fluency in primary students in Hong Kong. Creativity Research Journal, 13(3-4), 359-365. https:// doi.org/10.1207/S15326934CRJ1334_13

Cheung, P. C., \& Lau, S. (2010). Gender differences in the creativity of Hong Kong school children: Comparison by using the new electronic WallachKogan creativity tests. Creativity Research Journal, 22(2), 194-199. https:// doi.org/10.1080/10400419. 2010.481522

Cohen, J. (1992). A power primer. Psychological bulletin, 112(1), 155. https:// doi.org/10.1037/00332909.112.1.155

Cooper, R. B., \& Jayatilaka, B. (2006). Group creativity: The effects of extrinsic, intrinsic, and obligation motivations. Creativity Research Journal, 18(2), 153172. https://doi.org/10.1207/s15326934crj1802_3

Council of Europe. (2003). Non-formal education. Retrieved from https://rm.coe.int/2012compendium-non-formal-education/168077c10b

Cropley, A. J. (1978). Unterricht ohne Schablone. Wege zur Kreativität. (Lessons without a template. Ways to creativity) (2 ed.). Ravensburg: Otto Maier Verlag.

Cropley, A. J., \& Maslany, G. W. (1969). Reliability and factorial validity of the Wallach-Kogan creativity tests. British Journal of psychology, 60(3), 395-398. https:// doi.org/10.1111/j.20448295.1969.tb01213.x

Daniels, S. (2013). Facilitating creativity in the classroom: Professional development for K12 teachers. In M. B. Gregerson, J. Kaufman \& H. Snyder (Eds.), Teaching creatively and teaching creativity (pp. 3-14). New York: Springer. https://doi.org/10.1007/978-14614-5185-3_1

Descalço, L., \& Oliveira, P. (2018). Science Competitions: Do they foster learning. Presented at the 10th International Conference on Education and New Learning Technologies, Palma, Spain (pp. 13881394). https://doi.org/10.21125/edulearn.2018. 0440

Diakidoy, I.-A. N., \& Constantinou, C. P. (2001). Creativity in physics: Response fluency and task specificity. Creativity Research Journal, 13(3-4), 401410. https:// doi.org/10.1207/S15326934CRJ1334_ 17

Farrokhzad, S. (2015). Chancengleichheit? Bildungs- und Berufschancen von Mädchen und Frauen mit Migrationshintergrund in der Bundesrepublik Deutschland [Equal opportunity? Educational and professional opportunities for girls wan women with a migration background in the Federal Republic of Germany]. Paper presented at the Genderwissen Gendernutzen für die soziale Arbeit., Universität Duisburg-Essen. Retrieved from https:/ / www.netzwerk-

fgf.nrw.de/fileadmin/media/media-

fgf/download/publikationen/netzwerk_fgf_studi e_nr_21_f_web.pdf\#page $=27$

Fletcher, G. (2019). The Effect Of Learning To Play A Musical Instrument On Creative Ability In Middle School Students. South Carolina Junior Academy of Science. 210. Retrieved from https://scholar exchange.furman.edu/scjas/2019/all/210/

Flyvbjerg, B. (2006). Five misunderstandings about casestudy research. Qualitative inquiry, 12(2), 219-245. https:/ / doi.org/10.1177/1077800405284363

Gärtner, H. J. (1997). Kreativität im Chemieunterricht. [Creativity in chemistry lesson]. Naturwissenschaften im Unterricht, 8(12-20). 
Getzels, J. W., \& Jackson, P. W. (1962). Creativity and intelligence: Explorations with gifted students. Wiley. https:/ / doi.org/10.2307/40223437

Gneezy, U., Leonard, K. L., \& List, J. A. (2009). Gender differences in competition: Evidence from a matrilineal and a patriarchal society. Econometrica, 77(5), 1637-1664. https://doi.org/10.3982/ ECTA6690

Gneezy, U., Niederle, M., \& Rustichini, A. (2003). Performance in competitive environments: Gender differences. The quarterly journal of economics, 118(3), 1049-1074. https://doi.org/10.1162/003355303606 98496

Gottfredson, L. S. (1981). Circumscription and compromise: A developmental theory of occupational aspirations. Journal of Counseling psychology, 28(6), 545. https://doi.org/10.1037/ 0022-0167.28.6.545

Gottfredson, L. S. (1996). Gottfredson's theory of circumscription and compromise. Career choice and development, 179-232.

Gray, A. (2016). The 10 skills you need to thrive in Fourth Industrial Revolution. World Economic Forum. Retrieved from https://www.weforum.org/ agenda/2016/01/the-10-skills-you-need-to-thrivein-the-fourth-industrial-revolution/

Guilford, J. P. (1959). Three faces of intellect. American psychologist, 14(8), 469. https://doi.org/10.1037/ h0046827

Guilford, J. P., \& Hoepfner, R. (1976). Analyse der Intelligenz. Beltz: Weinheim/Basel.

Hu, W., \& Adey, P. (2002). A scientific creativity test for secondary school students. International Journal of Science Education, 24(4), 389-403. https://doi.org/ $10.1080 / 09500690110098912$

Janštová, V., Dvořáková, R., \& Jáč, M. (2016). Identifying the factors that motivate pupils toward science competitions. Paper presented at the ESERA 2015 Conference. Science education research: Engaging learners for a suitable future., Helsinki, Finland.

Jo, S. M. (2009). A study of Korean students' creativity in science using structural equation modeling (Doctoral dissertation). from The University of Arizona. Retrieved from https://repository. arizona.edu/handle/10150/193568

Jugend forscht e.V. (2019). Deutschlands beste Nachwuchsforscher zu Gast bei Angela Merkel. [Germany's best young researchers visit Chancellor Angela Merkel]. Retrieved from https://www. jugend-forscht.de/presse/pressemitteilungen/ archiv/jugend-forscht-deutschlands-bestenachwuchsforscher-zu-gast-bei-bundeskanzlerinangela-merkel.html

Jugend forscht e.V. (2020a). Erfolgreiche Ehemalige [Successfull former]. Retrieved from https://www.jugend-forscht.de/stiftung-jugendforscht-e-v/historie/erfolgreiche-ehemalige.html

Jugend forscht e.V. (2020b). Förderer [Sponsors]. Retrieved from https://www.jugend-forscht.de/ netzwerk/partner/foerderer.html

Jugend forscht e.V. (2020c). Information in English. Retrieved from https://www.jugend-forscht.de/ information-in-english.html

Jugend forscht e.V. (2020d). KMK \& Kultusministerien [Conference of Ministeries of Education and Arts $\mathcal{E}$ Ministeries of Education and Arts]. Retrieved from https://www.jugend-forscht.de/netzwerk/ partner/kmk-kultusministerien.html

Jugend forscht e.V. (2020e). Schirmherr [Patron]. Retrieved from https://www.jugendforscht.de/stiftung-jugend-forscht-e-v/stiftungjugend-forscht-e-v/schirmherr.html

Kämmerer, A. (2000). Kreativität und Geschlecht. [Creativity and Gender]. In R. M. Holm-Hadulla (Ed.), Kreativität (Vol. 44, pp. 301-327). Heidelberg Berlin,: Springer. https://doi.org/10.1007/978-3642-87237-2_15

Kaufman, J. C., \& Beghetto, R. A. (2009). Beyond big and little: The four c model of creativity. Review of general psychology, 13(1), 1-12. https://doi.org/ $10.1037 / \mathrm{a} 0013688$

Kennedy, H. L., \& Parks, J. (2000). Society cannot continue to exclude women from the fields of science and mathematics. Education, 120(3).

Kettler, T., Lamb, K. N., Willerson, A., \& Mullet, D. R. (2018). Teachers' Perceptions of Creativity in the Classroom. Creativity Research Journal, 30(2), 164171. https:// doi.org/10.1080/10400419.2018.1446 503

Kind, P. M., \& Kind, V. (2007). Creativity in science education: Perspectives and challenges for developing school science. Studies in Science Education, 43, 1-37. https://doi.org/10.1080/ 03057260708560225

Kirsten, B. (Producer). (2007). Prädiktoren einer Studienwahlentscheidung: die Entwicklung eines Studienwahlmodells auf Basis der" Theory of circumscription and compromise" nach Gottfredson (1981). [Predictors of a course choice: the development of a course choice model based on the "Theory of circumscription and compromise" by Gottfredson (1981)]. (Doctoral dissertation). Retrieved from http:/ / elpub.bib.uni-wuppertal.de/edocs/ dokumente/fbg/psychologie/diss2007/kirsten/ dg0702.pdf

Lau, S., \& Cheung, P. C. (2010a). Creativity assessment: Comparability of the electronic and paper-andpencil versions of the Wallach-Kogan Creativity Tests. Thinking Skills and Creativity, 5(3), 101-107. https:/ / doi.org/10.1016/j.tsc.2010.09.004 
Lau, S., \& Cheung, P. C. (2010b). Developmental trends of creativity: What twists of turn do boys and girls take at different grades? Creativity Research Journal, 22(3), 329-336. https://doi.org/10.1080/10400419. 2010.503543

Lengfelder, A., \& Heller, K. A. (2002). German Olympiad studies: Findings from a retrospective evaluation and from in-depth interviews: Where have all the gifted females gone. Journal of Research in Education, 12(1), 86-92.

Mahoney, J. L., Cairns, B. D., \& Farmer, T. W. (2003). Promoting interpersonal competence and educational success through extracurricular activity participation. Journal of educational psychology, 95(2), 409. https://doi.org/10.1037/ 0022-0663.95.2.409

Meyer, H. (2002). Unterricht analysieren, planen und auswerten. [Analyze, plan and evaluate lessons.]. Kiper, H., Meyer, H. Topsch, W. Einführung in die Schulpädagogik (S. 147-156). Berlin: Cornelsen Scriptor.

Miller, P. H., Slawinski Blessing, J., \& Schwartz, S. (2006). Gender Differences in High-school Students' Views about Science. International Journal of Science Education, 28(4), 363-381. https://doi.org/ $10.1080 / 09500690500277664$

Mohtar, L. E., Halim, L., \& Iksan, Z. H. (2016). Cognitive, Affective and Students' Achievement in Physics: A Hypothetical Model for Structural Equation Modeling testing. Paper presented at the 4th International Conference on ASEAN Comparative Education Research Network (ACERN), Padang - West Sumatra.

Mund, W. (2007). Jugend forscht und Jugend musiziert: kognitive Fähigkeiten und Persönlichkeitsmerkmale erfolgreicher Teilnehmer ["Jugend forscht" and "Jugend musiziert": cognitive abilities and personality traits of successful participants] (Doctoral dissertation), Philipps-Universität Marburg. Retrieved from http:/ / archiv.ub.uni-marburg.de/diss/z2008/ 0750/pdf/dwm.pdf

Niedersächsisches Kultusministerium (Hrsg.). (2012). Kerncurriculum für die integrierte Gesamtschule. Schuljahrgänge 5-10. Naturwissenschaften. Retrieved from https:/ / cuvo.nibis.de/cuvo.php?fulltextsearch_le v0_ov=\&skey_lev0_1000_ov=Dokumentenart\&sva lue_lev0_1000_ov=\&skey_lev0_1001_ov=Schulber eich\&svalue_lev0_1001_ov=\&skey_lev0_1002_ov= Schulform\&svalue_lev0_1002_ov=Integrierte+Ges amtschule\&skey_lev0_1003_ov=Fach\&svalue_lev0 _1003_ov=Naturwissenschaften\&p=search

Niedersächsisches Kultusministerium (Hrsg.). (2015). Kerncurriculum für das Gymnasium. Schuljahrgänge 510. Naturwissenschaften. Retrieved from https:/ / cuvo.nibis.de/cuvo.php?skey_lev0_0=Sch
ulform\&svalue_lev0_0=Integrierte+Gesamtschule \&skey_lev0_1=Fach\&svalue_lev0_1=Naturwissens chaften\&fulltextsearch_lev0_ov=\&skey_lev0_1000 _ov=Dokumentenart\&svalue_lev0_1000_ov=\&ske y_lev0_1001_ov=Schulbereich\&svalue_lev0_1001_ ov=\&skey_lev0_0_ov=Schulform\&svalue_lev0_0_ ov=Gymnasium-

Sek.I\&skey_lev0_1_ov=Fach\&svalue_lev0_1_ov=C hemie\&p=search

Niedersächsisches Kultusministerium (Hrsg.). (2017). Kerncurriculum für das Gymnasium - gymnasiale Oberstufe. Chemie. Retrieved from https://cuvo.nibis.de/cuvo.php?skey_lev0_0=Sch ulform\&svalue_lev0_0=Gymnasium-

Sek.I\&skey_lev0_1=Fach\&svalue_lev0_1=Chemie \&fulltextsearch_lev0_ov=\&skey_lev0_1000_ov=Do kumentenart\&svalue_lev0_1000_ov=\&skey_lev0 1001_ov=Schulbereich\&svalue_lev0_1001_ov=\&sk ey_lev0_0_ov=Schulform\&svalue_lev0_0_ov=Gy mnasiale+Oberstufe+-

+Gymnasium\&skey_lev0_1_ov=Fach\&svalue_lev0 _1_ov=Chemie\& $\mathrm{p}=$ search

OECD. (2017). OECD - Bildung auf einen Blick [OECD education at a glance]. Retrieved from http:/ / www.oecd.org/education/skills-beyondschool/EAG2017CN-Germany-German.pdf

OECD. (2018). The future of education and skills: education 2030: the future we want. OECD publishing. Retrieved from https:/ / www.oecd.org/education/2030/E2030\%2 OPosition\%20Paper\%20(05.04.2018).pdf

Oerke, B., \& Eigenstetter, M. (2018). MINT coach. Individuelle Intervention bei Schülerinnen zur Erkennung von MINT-Begabungen. Retrieved from https://mintcoach.net/fileadmin/user_upload/D okumente/MINTcoach_Maedchen_fuer_MINT_in teressieren.pdf

Omusonga, T. O., Indoshi, F. C., \& Achieng'Rabari, J. (2011). Differences in divergent thinking among secondary school physics students. Journal of Emerging Trends in Educational Research and Policy Studies, 2(4), 216-227.

Orvis, J. N., Sturges, D., Tysinger, P. D., Riggins, K., \& Landge, S. (2018). A Culture of Extrinsically Motivated Students: Chemistry. Journal of the Scholarship of Teaching and Learning, 18(1), 43-57. https:/ / doi.org/10.14434/josotl.v18i1.21427

Robelen, E. W. (2011). Awareness grows of importance of learning science beyond school. Education Week, $30(27), 2-5$.

Runco, M. A. (1986). Divergent thinking and creative performance in gifted and nongifted children. Educational and Psychological Measurement, 46(2), 375-384. https://doi.org/10.1177/0013164486046 00211 
Runco, M. A., \& Albert, R. S. (1985). The reliability and validity of ideational originality in the divergent thinking of academically gifted and nongifted children. Educational and Psychological Measurement, 45(3), 483-501. https://doi.org/10.1177/00131644 8504500306

Runco, M. A., \& Okuda, S. M. (1988). Problem discovery, divergent thinking, and the creative process. Journal of youth and adolescence, 17(3), 211-220. https:/ / doi.org/10.1007/BF01538162

Runco, M. A., Abdulla, A. M., Paek, S. H., Al-Jasim, F. A., \& Alsuwaidi, H. N. (2016). Which test of divergent thinking is best? Creativity. Theories-ResearchApplications, 3(1), 4-18. https://doi.org/10.1515/ ctra-2016-0001

Rüschenpöhler, L., \& Markic, S. (2020). Secondary school students' chemistry self-concepts: gender and culture, and the impact of chemistry self-concept on learning behaviour. Chemistry Education Research and Practice, 21(1), 209-219. https://doi.org/10.1039/C9RP00120D

Sahin, A. (2013). STEM clubs and science fair competitions: Effects on post-secondary matriculation. Journal of STEM Education, 14(1), 511.

Schuster, M., Sülzle, A., Winker, G., \& Wolffram, A. (2014). Neue Wege in Technik und Naturwissenschaft Zum Berufsverhalten von Mädchen und Frauen [New ways in technics and science - on the occational behaviour of girls and women]. Retrieved from https:/ / tore.tuhh.de/bitstream/11420/81/1/Gut achten_Berufswahlverhalten.pdf

Schwarz, J. (2020). Mann-Whitney-U-Test. Methodenberatung Universität Zürich. Retrieved from

https:/ / www.methodenberatung.uzh.ch/de/date nanalyse_spss/unterschiede/zentral/mann.html

Semmler, L., \& Pietzner, V. (2017). Creativity in chemistry class and in general-German student teachers' views. Chemistry Education Research and Practice, 18(2), 310-328. https://doi.org/10.1039/ C6RP00230G

Silvia, P. J., Winterstein, B. P., Willse, J. T., Barona, C. M., Cram, J. T., Hess, K. I., . . . Richard, C. A. (2008). Assessing creativity with divergent thinking tasks: Exploring the reliability and validity of new subjective scoring methods. Psychology of Aesthetics, Creativity, and the Arts, 2(2), 68. https:/ / doi.org/10.1037/1931-3896.2.2.68

Smith, G., \& Carlsson, I. (1985). Creativity in middle and late school years. International Journal of Behavioral Development, 8(3), 329-343. https://doi.org/ $10.1177 / 016502548500800307$

Springub, A., Semmler, L., Uchinokura, S., \& Pietzner, V. (2017). Chemistry Teachers' Perceptions and
Attitudes Towards Creativity in Chemistry Class Cognitive and affective aspects in science education research (pp. 41-54). Springer. https:/ / doi.org/10.1007/978-3-319-58685-4_4

Stang, J., Urhahne, D., Nick, S., \& Parchmann, I. (2014). Wer kommt weiter? Vorhersage der Qualifikation zur Internationalen Biologie-und ChemieOlympiade auf Grundlage des Leistungsmotivations-Modells von Eccles. Zeitschrift für pädagogische Psychologie. https:/ / doi.org/10.1024/1010-0652/a000127

Starko, A. J. (2010). Creativity in the classroom: Schools of curious delight (4th ed.). New York: Routledge. https:/ / doi.org/10.4324/9780203871492

Starko, A. J. (2018). Creativity in the classroom: schools of curious delight (6 $6^{\text {th }}$ ed.). New York: Routledge, Taylor \& Francis. https://doi.org/10.4324/ 9781315391625

Steegh, A. M., Höffler, T. N., Keller, M. M., \& Parchmann, I. (2019). Gender differences in mathematics and science competitions: A systematic review. Journal of Research in Science Teaching, 56(10), 1431-1460. https://doi.org/ $10.1002 /$ tea. 21580

Storme, M., Lubart, T., Myszkowski, N., Cheung, P. C., Tong, T., \& Lau, S. (2017). A Cross-Cultural Study of Task Specificity in Creativity. The Journal of Creative Behavior, 51(3), 263-274. https://doi.org/ 10.1002/jocb.123

Suardiman, S. P., \& Kumara, A. (2018). Parental involvement in elementary school-aged child's creativity. Paper presented at the IOP Conference Series: Materials Science and Engineering. https:/ / doi.org/10.1088/1757-899X/296/1/ 012051

Taskinen, P. H. (2010). Naturwissenschaften als zukünftiges Berufsfeld für Schülerinnen und Schüler mit hoher naturwissenschaftlicher und mathematischer Kompetenz: eine Untersuchung von Bedingungen für Berufserwartungen (Doctoral Dissertation). Faculty of Mathematics and Natural Sciences, Christian Albrechts University in Kiel. Retrieved from https:/ / macau.uni-

kiel.de/servlets/MCRFileNodeServlet/dissertatio n_derivate_00003501/diss_taskinen.pdf

Tobin, K., \& Garnett, P. (1987). Gender Related Differences in. Science Education, 71(1), 91-103. https:/ / doi.org/10.1002/sce.3730710112

Torrance, E. P. (1966). Torrance tests of creative thinking: Norms-technical manual: Verbal tests, forms $a$ and $b$ : Figural tests, forms $a$ and $b$ : Personal Press, Incorporated.

Urban, K. K. (1991). On the creativity development in children. Creativity Research Journal, 4, 177-191. https:/ / doi.org/10.1080/10400419109534384 
Urban, K. K. (2004). Kreativität: Herausforderung für Schule, Wissenschaft und Gesellschaft. [Creativity. Challange for school, science and society.]. Münster: LIT Verlag.

Wakefield, J. F. (1985). Towards creativity: Problem finding in a divergent-thinking exercise. Child Study Journal.

Wallach, M. A., \& Kogan, N. (1965). Modes of thinking in young children. New York: Holt, Rinehart, \& Winston.

Webb, N. M. (1984). Sex differences in interaction and achievement in cooperative small groups. Journal of educational psychology, 76(1), 33. https://doi.org/ 10.1037/0022-0663.76.1.33
Westby, E. L., \& Dawson, V. L. (1995). Creativity: Asset or burden in the classroom? Creativity Research Journal, 8(1), 1-10. https://doi.org/10.1207/ s15326934crj0801_1

Wirt, J. L. (2011). An analysis of Science Olympiad participants' perceptions regarding their experience with the science and engineering academic competition (Doctoral Dissertation). Seton Hall University. Retrieved from https:/ / scholarship.shu.edu/cgi/v iewcontent.cgi? article $=1014 \&$ context $=$ dissertations

Wu, W.-T., \& Chen, J. D. (1999). A follow-up study of Taiwan physics and chemistry olympians-the environmental influences. Retrieved from https:/ / www.childresearch.net/projects/special/ 1999_01.html

\section{http://www.ejmste.com}

